Стефан В. Мандић ${ }^{1}$

\title{
ОДНОС ИЗМЕЪУ ЕКОНОМСКИХ, ГЕОПОЛИТИЧКИХ И ДЕМОГРАФСКИХ ПРОЦЕСА У САВРЕМЕНОМ СВЕТУ
}

\begin{abstract}
Апстракт: У савременом свету уочљива је веза између карактеристика демографске репродукције у одређеним друштвима, токова миграција и глобалних, економских и геополитичких процеса. Основни циљ овог рада биће налажење одговора на питање: постоји ли намера дела светских економских и политичких елита да се контролисањем и стимулацијом миграторних кретања утичу на економске токове и промену геополитичких односа у одређеним деловима света? Стога ћемо у раду разматрати разлике у демографским карактеристикама између развијених делова Европе (негативан природан прираштај и смањивање становништва) и неразвијених делова Африке и Азије (позитиван природан прираштај и повећање становништва), са посебним акцентом на питање да ли се потреба за радном снагом у развијеним деловима света надомешћује подстицањем емиграције из неразвијених делова света. Такође, испитаћемо какву улогу у подстицању миграција има финансијски капитал и његова тежња да се са повећаним приливом миграната у одређену државу повећава и њено задуживање због већег улагања у систем социјалне помоћи. Размотрићемо и да ли постоји намера да се контролом и стимулисањем мигрантских токова промени демографска структура појединих европских држава, уруши њихова стабилност, ефективност владавине над сопственом територијом и сувереност и да се тако ојача политичка надлежност наддржавних структура попут Европске уније. На крају, анализираћемо какав однос према мигрантском питању имају леви и десни покрети у Европи и упоредити ставове „суверенистичког“ и „глобалистичког“ политичког дискурса. Основни метод рада биће упоредна анализа економских и демографских показатеља и анализа дискурса различитих политичких парадигми.
\end{abstract}

Кључне речи: демографски процеси, економија, геополитика, идеологија, миграције.

\footnotetext{
1 sviosimjednog@gmail.com
} 


\section{Опште карактеристике глобалних миграција у 21. веку}

У савременом свету уочљиво је повећање глобалних миграција. Док је 1971. године број глобалних миграната износио 84 милиона људи, односно 2,8\% светске популације, 2015. године број глобалних миграната износио је 248 милиона људи, односно 3,4\% светске популације (World Migration Report, 2018). Претпостављамо да ће током 21. века број светских миграната још више расти због четири основна фактора. Пре свега због повећавања економске неједнакости између развијеног (Северозападне Европе и Северне Америке) и неразвијеног света (Латинске Америке, Африке и делова Азије) ${ }^{2}$ (Milanović, 2016). Затим, због тренда убрзаног раста популације у неразвијеним земљама који ће се, према неким проценама, зауставити тек око 2100. године (World Population Prospects, 2017). Један од фактора који може утицати на даљи раст глобалних миграција је и глобално загревање које ће потенцијално угрозити развој неразвијених земаља (пре свега преко негативног утицаја на пољопривредну производњу), нарочито оних које се налазе у подручју екватора (Field, Barros, 2014). Светске силе, које у намери да испуне своје геополитичке циљеве често подстичу ратове и дестабилизују одређена подручја, могу такође довести до значајних померања светског становништва у будућности.

Основни циљ овог рада је одговор на питање да ли делови глобалних економских и политичких елита, нарочито они који долазе из развијених држава Западне Европе и Северне Америке, намерно стимулишу глобалне миграције и, ако то чине, на који начин то служи њиховим интересима. Стога ћемо у даљем току рада у посебним поглављима анализирати утицај економских и политичких елита на степен глобалних миграција.

\footnotetext{
2 Иако се глобална неједнакост у задњих неколико деценија смањила, Милановић истиче да је то првенствено због економског успона Кине који је допринео томе да се значајни делови светске популације нарочито у Азији ослободе сиромаштва. Ипак, овај процес је пратило даље продубљивање економског јаза између најразвијенијих западних земаља и насиромашнијих, пре свега, афричких земаља.
} 


\section{Утицај економске елите на стимулисање глобалних миграција}

У најразвијенијим земљама услед ниске стопе фертилитета долази до пада броја становника (Carone, Costelo, 2007) и то утиче и на смањивање расположиве радне снаге потребне производном капиталу за репродукцију производње. Стога је у интересу овог дела економске елите да стимулише миграцију новог становништва како би се надоместила потреба за радном снагом. Доласком нових миграната може се, кроз повећавање резервне армије рада, утицати и на смањење просечне најамнине домаће радничке класе чиме се повећава њена експлоатација. Утицај миграција на смањивање просечних најамнина потврђено је у више емпиријских студија (Borjas 2003, Borjas and Katz, 2007). Такође, миграције омогућавају да се попуне она занимања којим домицилно становништво не жели да се бави.

Најбољи пример развијене земље у којој је економској елити у интересу да се повећају глобалне миграције како би се испунила потреба за новом радном снагом је Немачка. Готово све немачке „мејнстрим“ партије, попут Хришћанско-демократске уније, Социјал-демократске партије и Зелених, повезане су са крупним капиталом и имају више или мање благонаклон став према имиграцији, што се може врло лако уочити уколико се прочитају њихови партијски програми (For Germany that is good to live in, 2017; The German Greens outline an ambitious 10-point plan for the 2017 Bundestag elections, 2017). Занимљива је скорашња изјава директора Немачке агенције за запошљавање да је тој земљи потребно око 400.000 нових радника годишње да би се задовољио постојећи ниво производње (Telegraf, 2021). За сада се првенствено прихвата прилив радне снаге из Источне и Југоисточне Европе, док се према миграцијама са Блиског истока и Африке има донекле амбивалентнији став (Kauffman, 2010). У будућности ће се ово највероватније променити због константне потребе за новом радном снагом.

У привлачењу нове радне снаге, Немачка заузима проактиван став, што се може видети у изјавама државних званичника. Пример тога можда могу бити и чланци који, с времена на време, излазе у Блицу, српским новинама које контролише немачки капитал, са насловима попут „СРБИМА У НЕМАЧКОЈ И ВИШЕ ОД 3.000 ЕВРА МЕСЕЧНО! Ово су им плате у евро, а и за добру зараду не морају да знају језик“ (Živković, 2021), „ЖЕЛИТЕ ПОСАО У НЕМАЧКОЈ, А ИМАТЕ ВИШЕ ОД 45 ГОДИНА? Нова правила посебно су 
ригорозна за једну генерацију, али и добра за МЛАЂЕ ОД 25 ГОДИНА“ (Kovačević, 2019) итд.

Деловање немачке економске елите може имати разарајући утицај на стање неразвијених и средње-развијених земаља, јер одлазак радно способних становника који се налазе у фертилном периоду живота, може да угрози економску и демографску репродукцију ових земаља. Иако за сада не постоје конкретни докази за то, према неким ауторима из сфере публицистике, постоји намера да се немачка потреба за новом радном снагом задовољи миграцијама из Источне и Југоисточне Европе, да би се ова подручја потом попунила радном снагом са Блиског истока и из Африке. На постојање овакве намере може указати и студија Уједињених нација из 2001. године у којој се разматра да ли се проблем недостатка радне снаге услед ниског фертилитета у Европи и Северној Америци може решити поступном допуном и делимичном заменом домицилне популације новом мигрантском популацијом (Replacement Migration: Is it A Solution to Declining and Aging Populations?, 2001).

Поставља се питање да ли је овај талас миграција ка развијеним земљама неминовност 21. века или је могуће да се он због развитка нових објективних фактора заустави. Могуће је да ће развитак аутоматизације и све већа употреба робота у производњи смањити потребу за новом радном снагом и тиме оријентисати економске елите да на друге начине омогуће несметану репродукцију производње, што може довести до престанка стимулације нових миграција из економских разлога у 21. веку.

\section{Утицај финансијског дела економске елите на стимулисање миграција}

Пошто је у најразвијенијим земљама већ деценијама стагнантан раст реалних најамнина (Desilver, 2018), кредит добија све већу улогу у стимулисању потрошње. Прихватајући једну од варијанти марксистичке теорије о кризи капитализма (Clarke, 1994), ми смо става да кредитирање потрошње није значајно само за најразвијеније земље, већ и за целокупни светски капиталистички систем јер потрошња најразвијенијих западних земаља чини највећи удео светске агрегатне тражње чиме има битну улогу у омогућавању светске робне циркулације и тиме битно доприноси репродукцији глобалног капитализма. Карактеристично је да овај облик кредитиране потрошње није само основа агрегатне тражње појединачних 
домаћинстава, већ и државе. У периоду након економске кризе из 2008. године повећано је задуживање држава, поготово најразвијенијих. Државе су се задуживале, пре свега, да би одржавале све већу бирократску структуру, затим повећале агрегатну тражњу становништва, инвестирале у инфраструктурне пројекте са намером да преко мултиплицирајућег ефекта повећају економску активност итд.

Финансијском капиталу је одговарало повећање задужености држава јер му је на тај начин омогућено остваривање значајног профита и већа контрола над државним политичким и економским деловањима. Ми ћемо овде извести једну хипотезу, коју није могуће темељно доказати у раду оволиког обима. Може се претпоставити да су повећане миграције у најразвијеније земље одговарале финансијском капиталу јер су утицале на повећање трошкова социјалног обезбеђивања и интеграције новопридошлог становништва, што је последично повећало и потребу за задуживањем. Примери који могу да укажу да је ова хипотеза донекле исправна јесу повећање трошкова социјалне помоћи у Шведској, Немачкој и Сједињеним Америчким Државама услед повећане имиграције у ове земље.

Пошто део миграната није лако брзо интегрисати у тржиште рада због њихове неквалификованости, значајан број њих живи од гарантоване државне помоћи за незапослене. Иако се дуг Немачке и Шведске током мигрантске кризе смањивао, а повећао тек током пандемије вируса COVID19 , неконтролисани прилив недовољно обучених миграната би у дугорочној перспективи могао да преоптерети социјални систем ових држава и допринесе повећању државног дуга. У САД дуг је већ прешао 100\% БДП-а, а једна од значајних ставки потрошње које утичу на његово повећање јесте социјална помоћ коју добијају и илегални мигранти (Spotlight on SSI benefits for noncitizens, 2021). Интересантан је званичан податак министарства економије Данске према коме је ова држава уштедела 6,7 милијарди евра због тога што је спроводила рестриктивну политику према имигрантима током мигрантске кризе (Day, 2014). 
Политичка елита и употреба миграција зарад циљева унутрашње политике

Партије лево-либералне оријентације у развијеним западним земљама углавном благонаклоно гледају на долазак нових миграната у земљу, без обзира на то да ли су они легални или илегални (The German Greens outline an ambitious 10-point plan for the 2017 Bundestag elections, 2017; 2020 Democratic Party Platform,2020). Ово се може објаснити чињеницом да је већа шанса да ће за лево-либералне партије гласати појединци који долазе из мигрантских породица. Највећи број грађана турског порекла у Немачкој гласа за Социјал-демократску партију (Ricking, 2017). У САД демократе имају доминантну подршку међу латиноамеричком популацијом (Lopez et al., 2016) док у Енглеској постоји већа шанса да ће гласачи пакистанског порекла гласати за Лабуристе (Ali Shah, Khatana, 2017).

Може се закључити да део партија у најразвијенијим земљама тежи да кроз промену демографске структуре популације утиче на дугорочно учвршћивање своје владавине. Уочљиво је такође да се у одређеним земљама оваквим позицијама приближавају и партије десног центра попут немачке Хришћанско-демократске уније, иако би у начелу требало да буду против оваквих политика (For Germany that is good to live in, 2017). Најдаље су по овом питању отишле америчке демократе, које не само да се залажу за неконтролисане миграције у САД, већ и за дерегулацију изборног система, која би дефакто омогућила и илегалним мигрантима да учествују у гласању (2020 Democratic Party Platform, 2020; Noe-Bustamante \& Budiman, 2020).

Пошто је већина „мејнстрим“ партија на Западу, како десне тако и леве оријентације, повезана са крупним капиталом, њихов благонаклон став према миграцијама се може објаснити и тиме да оне као политички представници крупног капитала усвајајући овакво становиште подржавају интерес економске елите да смањи цену рада на домаћим тржиштима.

\section{Политичка елита и употреба миграција зарад геополитичких циљева}

Основно геополитичко усмерење англо-саксонских политичких елита јесте тежња ка дугорочном обуздавању Русије, а у последње време и Кине. Ово усмерење почело је да се развија још у 19., а свој пун облик добило 
је у 20 веку. Главни представници овог реалистичког геополитичког правца су били англо-саксонски интелектуалци попут Макиндера, Спајкмана, Бжежинског, Кисинџера и др. Према овом усмерењу, задатак Велике Британије и САД као таласократских (поморских) сила треба да буде спречавања евроазијског економског и политичког повезивања, чији су главни носиоци телурократске (копнене) државе попут, првенствено Русије, донекле Немачке и, од 21. века, Кине. Успешна економска и политичка интеграција Евроазије, као најнасељенијег и ресурсно најбогатијег супер-континента, смањила би значај САД и од њих направила другоразредну силу. Уколико САД желе да остану светски хегемон, оне морају да контролишу подручја између Кине, Немачке и Русије и на тај начин спрече њихово ближе повезивање које би довело до евроазијске интеграције. Стога је битно да контролишу рубна подручја око ових земаља, попут Источне Европе, Балкана, Блиског истока, Централне и Југоисточне Азије. Такође је битно да земљама у Западној Европи, попут Француске и Немачке, ограниче независно деловање кроз различите наднационалне организације попут ЕУ и НАТО, и тиме вежу њихову спољну политику за атлантистичке геополитичке циљеве (Proroković, 2018; Kisindžer, 2001).

САД су током деведесетих година биле неприкосновен светски хегемон. Ипак, од 21. века отпочиње процес њиховог постепеног слабљења. САД све теже контролишу процесе у Евроазији, постепено бивају истиснуте са евроазијских рубних подручја, не могу да обуздају јачање Русије и Кине, а све теже контролишу и поступке Немачке и Француске. Постоји објективна опасност да се током 21. века ЕУ, у којој главну реч има Немачка, све више економски и политички приближи Русији и Кини. Стога је наша теза да политичка елита САД покушава да кроз интервенционистичку политику у појединим земљама рубног подручја, нарочито на Блиском истоку и у Централној Азији, направи стање хаоса које ће покренути значајне миграције ка развијеним земљама Запада, нарочито ка Немачкој и Француској, што може да дестабилизује и ослаби ове земље и на тај начин их поновно интегрише под чврсту контролу Вашингтона. Нашу тезу потврђује чињеница да је значајан део невладиних организација, које помажу процес илегалних миграција ка западној Европи, финансиран и организационо потпомогнут од стране различитих фондација из САД. Према извештају америчке про-мигрантске организације под називом Национални комитет за одзивну филантропију, највећи финансијери 
невладиних организација које су помагале мигрантима да илегално прелазе границе током мигрантске кризе су америчке фондације попут Фонда за отворено друштво, Форд фондације, Фондације заједнице Силиконске долине, Карнеги корпорације Њу Јорка итд (State of Fondation Funding for Pro-imigrant Movement, 2019).

Емпиријска истраживања су показала да је вредносна хомогеност друштва предуслов његове дугорочне стабилности. Ова вредносна хомогеност је уско повезана са културном хомогеношћу. Уколико се у одређеном друштву налазе културе са радикално различитим вредносним обрасцима може доћи до унутрашњег сукоба који би ослабио његову стабилност и тиме утицао на смањивање степена његове суверености. Истраживање аустралијских економиста Гебремедина и Мависаклјана на узорку од 78 земаља је показало да је имиграција у обрнутој сразмери са политичком стабилношћу земље (Gebermedehin, Mavisaklyan, 2013). Лонгитудално истраживање на Универезитету у Келну у периоду између 2002. и 2010. године је показало да се са повећањем имиграције смањује друштвено поверење (Ziller, 2014). Такође, холандско истраживање је показало да повећана имиграција доводи до смањивања подршке за социјалне програме државе (Reeskens, Oorschot, 2012). Истраживање Оксфордског универзитета је показало да повећање религијске и етничке разноликости омета друштвену сарадњу, како на индивидуалном тако и на колективном нивоу (Aksoy, 2015).

Примери Немачке и Француске указују да стапање култура са различитим вредносним системима има потенцијал за дестабилизацију друштва и да је процес интеграције новопридошлих култура често спор и неизвестан. Потенцијал дестабилизације европских друштава који миграције доводе са собом према нама је управо оно што одговара САД и њиховом циљу спречавања евроазијске интеграције.

\section{Глобалистички и суверенистички дискурс о миграцијама}

Глобалистички приступ заснива се на становишту да у савременом друштву национална држава има све мањи значај и да основни облик организације у будућности треба да буду наднационалне политичке структуре. Овај приступ је углавном близак лево-либералним партијама у земљама Запада. У последњих неколико деценија за глобалистички приступ 
је карактеристично проширивање концепта људских права, тако да сада људска права у себе укључују и одређене појмове настале из теорије постмодернизма и нове левице. Глобалистички приступ је, према нама, у својој суштини наставак просветитељске мисли о неотуђивости људских права, допуњен идејом о месијанској и цивилизаторској улози Западног света, нарочито САД, у ширењу ове „тираније права“. У глобалистичкој парадигми сматра се да је подржавање неконтролисаних миграција морална обавеза сваког „пристојног“ човека. Свако ко на критички начин преиспитује глобалне миграције напада се са моралних становишта и означава пејоративним називима попут „фашисте“, „ксенофоба“ итд. Овакав став је логички некохерентан, јер противљење миграцијама не мора да буде карактеристика само десних политичких оријентација. Тако је, на пример, један од највећих противника миграција у САД током 20. века је био Цезар Чавез, познати левичар и вођа синдиката у којима су претежно чланство чинили Латиноамериканци (Pawel, 2014). У последњих неколико година присутна је пракса да се на друштвеним платформама цензуришу појединци који се противе миграцијама и да се искључују из јавног простора. Цензуром на интернету, глобалистичка парадигма упада у контрадикторност јер зарад своје „борбе за људска права“ укида право на слободу мишљења.

Суверенистички приступ противи се процесима глобализације и тежи да врати стари сјај националној држави. По правилу се противи глобалним миграцијама и ово противљење поткрепљује различитим економским, демографским, политичким и културним аргументима. У суверенисте спадају разноврсне политичке опције - од националистичке левице, преко либертаријанаца конзервативаца и популистичке деснице до фашистичких и ксенофобних покрета. Иако суверенисти неретко дају валидне критике глобалних миграција, они према нама углавном не нуде адекватна решења. Ниједан од суверенистичких покрета до сада није понудио кохерентан програм који би се на адекватан начин позабавио недостатком радне снаге и демографском кризом у развијеним државама, проблемом глобалне неједнакости која доприноси миграцијама, обуздавањем разорног деловања политичких и економских елита итд. 


\section{Уместо закључка}

Ми сматрамо да је најхуманије решење за глобалне миграције да се оне смање преко темељне реформе светског економског и политичког система. Пре свега развијене и средње развијене земље морају да покажу већу солидарност са неразвијеним земљама, тако што би на адекватан начин обезбедиле средства неопходна за њихов развој. Ово би могло да се постигне на тај начин што би се богатији део света обавезао да ће кроз новчану помоћ и пренос знања да помогне развитак најнеразвијенијих. Најразвијеније земље такође морају да преузму активнију улогу у „зеленој“ транзицији која би смањила емисију гасова са ефектом стаклене баште и тиме омогућила да се ова емисија повећа у неразвијеним земљама како би се оне успешно индустријализовале. Сламање америчке моћи и стварање мултиполарног света заснованог на међународном праву који би гарантовао безбедност земљама које немају значајну војну снагу и смањио број неоправданих војних интервенција, такође би утицало на смањење глобалних миграција. У одређеним областима неопходно је глобално деловање свих земаља да би се остварио глобални правни поредак који би ограничио неодговорно деловање крупног капитала, пре свега кроз укидање пореских рајева, развијање међународног закона о правима радника, реформу закона о патентима како би се омогућио бржи трансфер технологије ка најнеразвијенијим земљама итд. Уколико се ове мере не спроведу, сматрамо да ће глобалне миграције постати један од основних узрока нестабилности 21. века како у развијеним тако и у неразвијеним земљама.

\section{Литература}

Ali Shah, M., Khatna T. (14. 06.2017). British Pakistani voters helped surge for Labour Party, The News, Available at https://www.thenews.com.pk/ print/210523-British-Pakistani-voters-helped-surge-for-Labour-Party

Aksoy, 0. (2015.) Effects of Heterogeneity and Homophily on Cooperation, Social Psychology Quarterly, https://doi.org/10.1177/ 0190272515612403 
Borjas, J. G. (2003). The Labour Demand Curve is Downsloping: Reexemening the Impact of Immigration on the Labour Market. The Quaterly Jounal of Economics. Oxford: Oxford University Press. Available at https://www.jstor.org/stable/25053941

Borjas, J. G, Katz F. L. (2007). The Evolution of Mexican-Born Workforce in the United States. Mexican Immigration to the United States. Chicago: Chicago University Press. Available at https://www.nber.org/system/files/ chapters/c0098/c0098.pdf

Bžežinski, Z. (2001). Velika šahovska tabla. Podgorica: CID.

Carone G, Costello D. (2006). Can Europe Afford to Grow Old? Finance and Development (br. 3). Available at https://www.imf.org/external/pubs/ ft/fandd/2006/09/carone.htm

Clarke, S. (1994). Marx's Theory of Crisis. London: Palgrave Macmillan.

Day, M. (04.05.2014). Denmark's immigration laws save country 6 billion pounds. Daily Telegraph. Available at https://www.telegraph.co.uk/news/ worldnews/europe/denmark/8492822/Denmarks-immigration-laws-savecountry-6-billion.html

Democratic Party Platform 2020. (2020). Democratic Party Available at https://democrats.org/where-we-stand/party-platform/

Desilver, D. (07.08.2018) For most American workers, real wages have barely budged in decades. Pew Research Center. Available at https://www.pewresearch.org/fact-tank/2018/08/07/for-most-us-workersreal-wages-have-barely-budged-for-decades/

Fale im majstori za klimu, negovatelji... svi: Nemačka mora da uvozi 400.000 radnika godišnje (24.08.2021) Telegraf Available at https://biznis.telegraf.rs/info-biz/3380858-fale-im-majstori-za-klimunegovateljis-svi-nemacka-mora-da-uvozi-4000-radnika-godisnje

Field, C. B, Barros, V. R. (2014). Climate Change 2014 Impacts, Adaptation and Vulnerability. New York: Cambridge Press. Available at https://www.ipcc.ch/report/ar5/wg2/ 
For Germany that is good to live in. (2017). CDU. Available at https://archiv.cdu.de/system/tdf/media/dokumente/170816regierungsprogrammn-english-version.pdf?file $=1$

Gebermedehin A. T., Mavisaklyan A. (2013). Immigration and political stability. Kyklos. (br. 3) https://doi.org/10.1111/kykl.12024

Kauffman, A. (17.10.2010). Merkel says multi-cultural society has failed. AFP. Available at https://web.archive.org/web/20101020091230/http:// news.yahoo.com/s/afp/20101017/wl_afp/germanymuslimreligionimmigration

Kovačević, T. (21. 11. 2019.) Želite posao u Nemačkoj, a imate više od 45 godina? Nova pravila posebno rigorozna za jednu generaciju ali i dobra za mlađe od 25 godina. Blic. Available at https://www.blic.rs/biznis/vesti/posao-unemackoj/093ewfs

Lopez M. H. et al. (11. 10. 2016). Latinos and political parties. Pew Research Centar. Available at https://www.pewresearch.org/hispanic/ 2016/10/11/latinos-and-the-political-parties/

Noe-Bustamante L. \& Budiman T. (03. 04. 2020). Most of the 23 million immigrants elegible to vote in 2020 elections live just in five states. Pew Research Centar Available at https://www.pewresearch.org/fact-tank/2020/03/03/mostof-the-23-million-immigrants-eligible-to-vote-in-2020-election-live-in-just-fivestates/

Milanović, B. (2010). The Haves and the Haves-not: Brief History of Global Inequality. New York: Basic Books.

Pawel, M. (2014). The Crusades of Cesar Chavez: A Biography. New York: Bloomsbury

Пророковић, Д. (2018). Геополитика Србије: Положај и перспективе на почетку 21. века. Београд: Службени гласник.

United Nations. (2021). Replacement Migration: Is it A Solution to Declining and Aging Populations? Available at https://www.un.org/ development/desa/pd/sites/www.un.org.development.desa.pd/files/unpdegm_200010_un_2001_replacementmigration.pdf

United Nations. (2017). World Migration Report. Geneva: International Organization for Migration. Available at https://www.iom.int/sites/g/ 
files/tmzbdl486/files/country/docs/china/r5_world_migration_report_2018_en .pdf

United Nations. (2017). World Population Prospects. New York: Departament of Economic and Social affairs. Available at https://population.un.org/wpp/Publications/Files/WPP2017_KeyFindings.pdf

Reeskens T., Oorschot van V, (2012.) Disentangling the 'New Liberal Dilemma': On the relation between general welfare redistribution preferences and welfare chauvinism. International Journal of Comparative Sociology. (br. 2) https://doi.org/10.1177/0020715212451987

Ricking, C. (24.08.2017). How will Turksih Germans vote in the country's upcoming elections? DW. Available at https://www.dw.com/en/how-will-turkishgermans-vote-in-the-countrys-upcoming-election/a-40229374

Spotlights on SSI Benefits for Noncitizens. (2021). Social Security Agency. Available at https://www.ssa.gov/ssi/spotlights/spot-non-citizens.htm

State of Fondation Funding for Pro-imigrant Movement. (2019). National Commity for Responsive Philantropy. Available at https://www.ncrp.org/initiatives/movement-investment-project/our-activemovement-areas/pro-immigrant-and-refugee-movement/state-foundationfunding

The German Greens outline an ambitious 10-point plan for the 2017 Bundestag elections. (2017). European Greens. Available at https://europeangreens.eu/news/german-greens-outline-ambitions-10-pointplan-2017-bundestag-elections

Zimmer, C. (2014). Ethnic Diversity, Economic and Cultural Contexts, and Social Trust: Cross-Sectional and Longitudinal Evidence from European Regions, 2002-2010. Social Forces (br. 3) Available at https://academic.oup.com/sf/ article-abstract/93/3/1211/2332107

Živković, M. (09.08.2021). Srbima u Nemačkoj i više od 3000 evra mesečno! Ovo su plate u evro, a i za dobru zaradu ne moraju da znaju jezik! Blic. Available at https://www.blic.rs/biznis/moj-novcanik/srbima-u-nemackoj-i-vise-od-3000evra-mesecno-ovo-su-im-plate-u-evro-a-i-za-dobru/2fe2gq8 


\section{Stefan Mandić}

\section{Summary}

\section{The Relationship Betwen Demographic, Economic and Geopolitical Processes in The Modern World}

In the modern world, there is a noticeable connection between the characteristics of demographic reproduction in certain societies, migration flows and global economic and geopolitical processes. The main goal of this paper will be to determine whether there is an intention on the part of world economic and political elites to influence economic flows and change geopolitical relations in certain parts of the world by controlling and stimulating migratory movements. Therefore, we will consider the differences in demographic characteristics between developed Europe (population decline) and underdeveloped parts of Africa and Asia (population growth) with special emphasis on the question of whether the need for labor in developed parts of the world is compensated by encouragement of immigration from underdeveloped parts of the world. We will also consider the role of financial capital in encouraging migration to a certain country and its interest to increase state's indebtedness due to increased investment in the migrant oriented social welfare system. We will also investigate whether the control and encouragement of migrant flows is intended to change the demographic structure of certain European countries, collapse their stability, effectiveness of rule over their own territory and sovereignty, and thus strengthen the political competence of supranational structures such as the European Union. Finally, we will analyze the attitude of the left and right movements in Europe towards the migrant issue and analyze the differences between the "sovereignist" and the "globalist" political discourse. The basic method of work will be a comparative analysis of economic and demographic indicators and a discourse analysis of different political paradigms.

Keywords: demographic processes; economy; geopolitics; ideology; migrations. 